\title{
PENGARUH DISIPLIN KERJA TERHADAP KINERJA KARYAWAN PADA PT. LEMATANG DI TANJUNG ENIM
}

\author{
Agusri \\ Dosen STIE Serasan Muara Enim \\ email:Agusri.a@yahoo.com
}

\begin{abstract}
ABSTRAK
Penelitian ini bertujuan untuk mengetahui berapa besar pengaruh Disiplin Kerja Terhadap Kinerja Karyawan, berdasarkan data primer dan data sekunder yang diperoleh melalui observasi, wawancara dan kuesioner. Populasi dan sampel dalam penelitian ini 58 karyawan Metode penelitian menggunakan analisa kuantitatif dan kualitatif, metode analisa kualitatif menggunakan uji validitas, menggunakan uji analisa regresi sederhana, uji analisa korelasi. Jumlah responden penelitian sebanyak 58 responden.Variabel bebas penelitian ini yaitu disiplin kerja dan variabel terikatnya yaitu kinerja karyawan.Hasil uji statistik untuk pengaruh disiplin kerja terhadap kinerja karyawan didapat nilai $t_{\text {hitung }}(3,833)>t_{\text {tabel }}(1,684)$, yang artinya tedapat pengaruh positif antara disiplin kerja dengan kinerja karyawan.Angka konstanta yang didapat yaitu sebesar 11,553 yang berarti jika tidak ada disiplin kerja, maka nilai konstanta 11,553 . Nilai koefisien regresi sebesar 0,343 yang menunjukkan bahwa setiap penambahan $1 \%$ disiplin kerja, maka kinerja karyawan akan meningkat sebesar 0,343 . terdapat pengaruh positif antara disiplin kerja dengan kinerja karyawan.
\end{abstract}

\section{Kata kunci : Disiplin, Kinerja}

\section{PENDAHULUAN \\ Latar Belakang}

Semakin kerasnya kompetisi bisnis dewasa ini memaksa perusahaanperusahaan untuk memberdayakan dan mengoptimalkan segenap sumber daya yang dimiliki perusahaan guna mempertahankan kelangsungan hidup perusahaan tersebut.Dalam usaha pencapaian tujuan perusahaan, permasalahan yang dihadapi manajemen bukan hanya terdapat pada bahan mentah, alat-alat kerja, mesin-mesin produksi, uang dan lingkungan kerja saja, tetapi juga menyangkut karyawan yang mengelola faktor-faktor produksi lainnya tersebut. Makin besar perusahaan, makin banyak karyawan yang bekerja didalamnya, sehingga besar kemungkinan timbulnya permasalahan manusiawi ini tergantung dari dari mana karyawan itu berasal. Makin beragam nilai yang dianut para karyawan, makin banyak konflik yang berkembang. Menurut Prof. Dr. Veithzal Rivai Zainal (2005:05)Manajemen sumber daya manusia (MSDM) merupakan salah satu bidang dari manajemen umum yang meliputi segisegi perencanaan, pengorganisasian, pelaksanaan dan pengendalian.

Suatu organisasi atau perusahaan dituntut memiliki pandangan dan sikap disiplin untuk meningkatkan produktivitas pegawai. Menurut Prof. Dr. H. Veithzal Rivai Zainal (2009;599) Disiplin kerja adalah suatu alat yang digunakan para manajer untuk berkomunikasi para manajer untuk berkomunikasi dengan karyawan agar mereka bersedia untuk mengubah suatu perilaku serta sebagai suatu upaya untuk meningkatkan kesadaran dan kesediaan seseorang mentaati semua peraturan perusahaan dan norma-norma yang berlaku.

Pendapat lain di kemukakan Malayu Hasibuan ( 2017: 112 ) menyatakan kedisiplinan adalah kesadaran dan kesediaan seseorang mentaati semua peraturan dan norma-norma social yang berlaku. Disiplin kerja merupakan salah satu komponen yang turut menentukan baik buruknya kinerja seseorang.Karyawan yang disiplin dalam bekerja akan cenderung untuk melakukan segala aktivitasnya sesuai 
dengan aturan, standar maupun tugas dan tanggung jawab yang menjadi kewajibannya..

Menurut Helfert (dalam buku Veithzal Rivai, M.B.A 2009:447) Kinerja adalah suatu tampilan keadaan secara utuh atas perusahaan selama periode waktu tertentu, merupakan hasil atau prestasi yang dipengaruhi oleh kegiatan operasional perusahaan dalam memanfaatkan sumber-sumber daya yang dimiliki. Kedisiplinan menjadi kunci terwujudnya tujuan perusahaan, dengan disiplin yang baik berarti karyawan sadar dan bersedia mengerjakan semua tugasnya dengan baik.

Dari hasil observasi penulis secara langsung penulis melihat ada beberapa karyawan yang belum sepenuhnya mematuhi disiplin kerja, dimana karyawan masih sering terlihat datang terlambat, masih adanya karyawan yang tidak menghargai waktu kesepakatan kerja, adanya sikap malas-malasan apabila tidak diperhatikan atasan, tidak menggunakan alat kerja dan pelindung diri pada saat bekerja di lapangan.

\section{Rumusan Masalah}

Berdasarkan latar belakang permasalahan tersebut diatas penulis tertarik untuk mengetahui permasalahan dalam penelitian ini yaitu apakah terdapat pengaruh disiplin kerja terhadap kinerja karyawan .

\section{Landasan teori}

\section{Pengertian Disiplin Kerja}

Menurut Singodimedjo dalam buku Prof. DR. Edy Sutrisno, M.Si (2009:86), mengatakan disiplin adalah sikap kesediaan dan kerelaan seseorang untuk mematuhi dan menaati norma-norma peraturan yang berlaku di sekitarnya. Disiplin pada hakikatnya adalah memanfaatkan sumbangan kemampuan secara optimal, dengan kesadaran, kesediaan, dan kepatuharnnya pada aturan dan perintah yang ditetapkan organisasi.

2. Indikator Disiplin Kerja

Menurut Handoko dalam buku Arif Yusuf Hamali (2016:216-218) indikator disiplin kerja adalah sebagai berikut:

a) Preventif Dicipline (disiplin preventif), yaitu adalah kegiatan yang dilaksanakan untuk mendorong para karyawan agar mengikuti berbagai standar dan aturan, sehingga penyelewengan-penyelewengan dapat dicegah. Sasaran pokoknya adalah untuk mendorong disiplin diri di antara para karyawan.. Pedoman dalam melakukan tindakan pendisiplinan preventif adalah Kehadiran, Penggunaan Jam Kerja dan tanggung Jawab

b) Correctif Dicipline (disiplin korektif), adalah kegiatan yang diambil untuk menangani pelanggaran terhadap aturan-aturan dan menoga untuk menghindari pelanggaran-pelanggaran lebih lanjut.

c) Progresif Dicipline (disiplin progresif), perusahaan bisa menerapkan suatu kebijaksanaan disiplin progresif, artinya memberikan hukuman-hukuman yang lebih berat terhadap pelanggaran-pelanggaan yang berulan.. Pedoman dalam melakukan tindakan disiplin progresif adalah: teguran lisan,teguran tertulis, hukuman yang berat dan diberhentikan dari pekerjaan

3. Faktor-faktor yang mempengaruhi Disiplin Kerja

Menurut Sutrisno, (2010 :89-92) faktor-faktor yang mempengaruhi disiplin kerja karyawan adalah besar kecilnya pemberian kompensasi, ada tidaknya keteladanan pimpinan dalam perusahaan, ada tidaknya aturan pasti yang dapat 
dijadikan pegangan, keberanian pimpinan dalam mengambil tindakan, ada tidaknya pengawasan pimpinan, ada tidknya perhatian kepada para karyawan

4. Pengertian Kinerja

Menurut Arif Hamali, S. S (2016:98) kinerja adalah keluaran yang dihasilkan oleh fungsi-fungsi atau indikator-indikator suatu pekerjaan atau suatu profesi-dalam waktu tertentu.Kinerja adalah hasil kerja yang dicapai oleh pegawai atau perilaku nyata yang ditampilkan sesuai dengan perannya dalam organisasi. Kemudian Prof. Dr. H. Veitzhal Rivai, M.B.A (2003:548) mengemukakan kinerja merupakan suatu fungsi dari motivasi dan kemampuan untuk menyelesaikan tugas atau pekerjaan seseorang sepatutnya memiliki derajat kesediaan dan tingkat kemampuan tertentu.

5. Aspek-aspek yang dinilai kinerja karyawan

Adapun aspek-aspek yang dinilai penilaian kinerja karyawan menurut Prof. Dr. H. Veitzhal Rivai, M.B.A (2003:563) diantaranya kemampuan teknis, kemampuan konseptual, kemampuan hubungan interpersonal, yaitu antara lain kemamuan untuk bekerja sama dengan orang lain, memotivasi karyawan, melakukan negoisasi.

6. Indikator Kinerja Karyawan

Menurut Anwar Prabu Mangkunegara (2010:75) indikator untuk mengukur kinerja karyawan secara individu ada empat yaituKualitas, Kuantitas, Pelaksanaan tugas, dan tanggung jawab..

7. Faktor-faktor kinerja karyawan

Kinerja karyawan merupakan hasil sinergi dari sejumlah faktor, yang terdiri dari (Wirawan, 2012: 7-8), faktor internal karyawan, Faktor Lingkungan Eksternal Organisasi

\section{Metode Penelitian}

Metode analisis data yang digunakan adalah metode analisis kuantitatif dan kualitatif.Meotde analisis kuantitatif merupakan suatu analisis yang digunakan untuk mengolah hasil penelitian guna memperoleh kesimpulan dari variabel yang diutarakan dalam bentuk angka-angka.Data yang digunakan dalam penelitian ini adalah data primer merupakan data yang diperoleh dari responden melalui penyebaran questioner.( Sugiyono 2013: 137)

\section{Populasi dan Sampel \\ Populasi}

Sugiyono (2013:115) populasi adalah wilayah generalisasi yang terdiri atas objek dan subjek yang mempunyai karakteristik tertentu yang ditetapkan oleh peneliti untuk dipelajari dan kemudian ditarik kesimpulannya. Populasi berjumlah 68 karyawan.

\section{Sampel}

Menurut Sugiyono (2013:116) proportionate stratified random sampling adalah teknik yang digunakan bila populasi mempunyai anggota/unsur yang tidak homogen dan bersifat proposional dengan cara:

Jumlah sampel per bagian $=\frac{\text { Jumlah sampel }}{\text { jumlah populasi }} \times$ jumlah karyawan per bagian 
Tabel 1

Perhitungan Jumlah Sampel

\begin{tabular}{|c|c|c|c|}
\hline No & Bagian & Perhitungan & Jumlah Sampel \\
\hline \hline 1 & $\begin{array}{c}\text { Administrasi/Staf/Koordinator/Pe } \\
\text { ngawas }\end{array}$ & $\frac{58}{68} \times 17=14,5$ & 15 \\
\hline 2 & Operator/Sopir & $\frac{58}{68} \times 46=39,235$ & 39 \\
\hline 3 & Security & $\frac{58}{68} \times 5=4,264$ & 4 \\
\hline \multicolumn{3}{|c|}{ Jumlah } & 58 \\
\hline
\end{tabular}

Sumber : Data diolah peneliti

\section{Teknik Pengumpulan Data}

\section{a. Observasi}

Teknik pengumpulan data yang dilakukan melalui hasil pengamatan secara langsung pada obyek penelitian terutama mengenai disiplin kerja .

b. Wawancara

Teknik pengumpulan data apabila peneliti ingin melakukan studi pendahuluan untuk menenmukan permasalahan yang akan diteliti dengan melakukan wawancara dan tanya jawab secara langsung dengan sejumlah karyawan.

\section{c. Kuesioner}

Kuesioner adalah metode pengumpulan data yang dilakukan dengan menyusun daftar pertanyaan yan dibagikan kepada karyawan dengan memberikan tanda $(\sqrt{ })$ pada salah satu jawaban yang sesuai menurut pendapat responden

\section{Teknik Analisa Data}

Metode analisis data terdiri atas metode analisis kuantitatif dan kualitatif.Meotde analisis kuantitatif merupakan suatu analisis yang digunakan untuk mengolah hasil penelitian guna memperoleh kesimpulan dari variabel yang diutarakan dalam bentuk angka-angka. Sedangkan metode analisis kualitatif merupakan analisis yang bertolak pada data dan lebih memanfaatkan teori yang ada sebagai bahan penjelas serta berakhir dengan teori atau gambaran tentang analisis kualitatif tersebut

\section{Uji Validitas}

Menurut Sugiyono (2013:455) Uji Validitas adalah suatu ukuran yang menunjukan tingkat validan, reliable dan objektif dalam derajat ketepatan antara dua data yang dapat dilaporkan oleh penelitian. Uji validitas digunakan untuk mengukur sah (valid) atau tidaknya suatu kuesioner. Uji validitas dihitung dengan membandingkan nilai $r$ hitung (correlated item total correlation) dengan nilai $r$ tabel. Jika $r$ hitung $>r$ tabel dan nilai positif pertanyaan tersebut dinyatakan valid.

\section{Analisis regresi linear sederhana}

Regresi linear sederhana yaitu untuk menganalisis seberapa besar pengaruh antara beberapa variabel independen. Bentuk umum persamaan regresi adalah sebagai berikut: 


$$
\begin{aligned}
& \mathrm{Y}=\mathrm{a}+\mathrm{bX} \\
& \mathrm{a}=\frac{\left(\sum \mathrm{y}\right)\left(\sum \mathrm{x}^{2}\right)-\left(\sum \mathrm{x}\right)\left(\sum \mathrm{xy}\right)}{\mathrm{n}\left(\sum \mathrm{x} 2\right)-\left(\sum \mathrm{x}\right)^{2}} \\
& \mathrm{~b}=\frac{\left(\sum \mathrm{xy}\right)-\left(\sum \mathrm{x}\right)\left(\sum \mathrm{y}\right)}{\mathrm{n}\left(\sum^{2}\right)-\left(\sum \mathrm{x}\right)^{2}} \\
& \text { Dimana }: \quad \mathrm{Y}: \text { Kinerja } \\
& \mathrm{a}: \text { Konstanta } \\
& \mathrm{b}: \text { Koefisien regresi (kemiringan) } \\
& \mathrm{x}: \text { Disiplin }
\end{aligned}
$$

\section{Analisis Korelasi}

Analisis korelasi berguna untuk menentukan suatu besaran yang menyatakan seberapa kuat hubungan suatu variabel dengan variabel lainnya. Untuk hubungan nilai koefisien korelasi dinyatakan dalam positif $(+)$ dan negatif $(-)$, atau $(-1 \leq \mathrm{r} \leq+$ 1), artinya jika :

a. $\mathrm{r}=1$, hubungan $\mathrm{x}$ dan y sempurna dan positif

(mendekati 1, hubungan sangat kuat dan positif)

b. $r=1$, hubungan $x$ dan y sempurna dan negatif

(Mendekati -1, hubungan sangat kuat dan negatif)

\section{Koefisien Determinasi}

Dalam analisis korelasi terdapat suatu angka yang disebut dengan koefisien determinasi yaitu digunakan untuk mengetahui uraian yang dapat diterangkan oleh persamaan regresi serta untuk mengetahui seberapa besar variabel yang dapat diterangkan oleh variabel $\mathrm{X}$, yang besarnya adalah kuadrat dari koefisien korelasi $\left(\mathrm{r}^{2}\right)$.

$\mathrm{R}=\left(\mathrm{r}^{2}\right) \times 100 \%$

Keterangan : $\mathrm{R}=$ koefisien determinasi. $\mathrm{r}=$ Koefisien korelasi

\section{Hasil Penelitian}

1. Pengujian Kualitas Data

a. Uji Validitas

Dalam penelitian ini uji validitas dapat dilakukan dengan metode korelasi Croncbach Alpha. Pada metode Cronbach's Alpha nilai R-hitung diwakili oleh nilai Corrected Item-Total Correlation, dengan menggunakan bantuan SPSS Versi 21 for Windows. Nilai tersebut kemudian dibandingkan dengan $\mathrm{r}$ tabel yang dicari pada tingkat (signifikasi 0,1 dengan uji 2 sisi) dan jumlah data sebanyak $(n)=58$ sehingga diperoleh nilai $r$ tabel sebesar 0,266. Dalam pengujian validitas data.

1). Validitas Disiplin

Dari out put dapat diketahui nilai korelasi antara skor item X (Disiplin) dam skor Total X (Disiplin). Nilai ini kita bandingkan dengan $r$ tabel, $r$ tabel dapat dicari pada taraf signifikasi 0,1 dengan uji 2 sisi dan jumlah data $(n)=58$, maka didapat $r$ tabel sebesar 0,266. Tabel berikut ini menyajikan hasil uji validitas untuk masingmasing item pertanyaan variabel Disiplin dalam kuesioner.

\section{Tabel 2.}

Hasil Uji Validitas variabel Disiplin

\begin{tabular}{|l|l|l|l|l|}
\hline No & Pertanyaan & $\mathbf{r}$ hitung & $\mathbf{r}$ tabel & Keterangan \\
\hline
\end{tabular}




\begin{tabular}{|l|l|l|l|l|}
\hline 1 & Item 1 & 0,450 & 0,266 & Valid \\
\hline 2 & Item 2 & 0,599 & 0,266 & Valid \\
\hline 3 & Item 3 & 0,765 & 0,266 & Valid \\
\hline 4 & Item 4 & 0,706 & 0,266 & Valid \\
\hline 5 & Item 5 & 0,527 & 0,266 & Valid \\
\hline 6 & Item 6 & 0,292 & 0,266 & Valid \\
\hline
\end{tabular}

Sumber: Hasil olah data

2). Variabel Kinerja

Dari out put dapat diketahui nilai korelasi antara skor item Y (Kinerja) dan skor total Y (Kinerja). Nilai ini kita bandingkan dengan $r$ tabel, $r$ tabel dapat kita cari pada taraf signifikansi 0,1 dengan uji 2 sisi dan jumlah data $(n)=58$, maka $r$ tabel sebesar 0,266 . Tabel berikut ini menyajikan hasil uji validitas untuk masing-masing item pertanyaan variabel kinerja dalam kuesioner.

Tabel 3.

Hasil Uji Validitas Kinerja

\begin{tabular}{|c|c|c|c|c|}
\hline No & pertanyaan & r hitung & r tabel & Keterangan \\
\hline 1 & Item 1 & 0,391 & 0,266 & Valid \\
\hline 2 & Item 2 & 0,624 & 0,266 & Valid \\
\hline 3 & Item 3 & 0,702 & 0,266 & Valid \\
\hline 4 & Item 4 & 0,338 & 0,266 & Valid \\
\hline 5 & Item 5 & 0,298 & 0,266 & Valid \\
\hline 6 & Item 6 & 0,287 & 0,266 & Valid \\
\hline
\end{tabular}

Sumber: Hasil olah data, 2018

b. Uji Realibilitas

Realibilitas menunjukkan sejauh mana suatu hasil pengukuran dapat dipercaya dan terbebas dari kekeliruan pengukuran. Dalam penelitian ini uji reliabilitas dilakukan dengan metode Cronbach's Alpha. Nilai yang telah diperoleh dengan metode tersebut kemudian dibandingkan dengan koefisien berdasarkan kriteria penerimaan reliabilitas yaitu lebih besar dari 0,6.

1. Variabel Disiplin (X)

Uji reliabilitas variabel Disiplin menggunakan SPSS versi 21 for windows yaitu dengan hasil :

Tabel 4.

Reliabilitas Statistik Variabel Disiplin

\begin{tabular}{|c|c|c|}
\hline $\begin{array}{c}\text { Cronbach's } \\
\text { Alpha }\end{array}$ & N of Item & Hasil Reliabilitas \\
\hline .703 & 7 & Reliabel \\
\hline
\end{tabular}

Sumber : Hasil Pengolahan data dari kuesioner

Hasil uji reliabilitas didapat dari cronbach's Alpha sebesar 0,703 $\geq 0,6$.

Karena ini diatas 0,6 maka dapat disimpulkan bahwa alat ukur dalam penelitian ini reliabel dan dapat dijadikan alat ukur untuk analisis selanjutnya.

2. Variabel Kinerja

Uji reliabilitas variabel volume penjualan menggunakan SPSS versi 21 for windows yaitu dengan hasil :

Tabel 5

Reliabilitas Statistik Variabel Kinerja 


\section{Reliability Statistics}

\begin{tabular}{|c|c|c|}
\hline $\begin{array}{l}\text { Cronbach's } \\
\text { Alpha }\end{array}$ & $\begin{array}{c}\text { Cronbach's Alpha Based on } \\
\text { Standardized Items }\end{array}$ & $\mathrm{N}$ of Items \\
\hline 619 & ,559 & 7 \\
\hline
\end{tabular}

Sumber : Hasil diolah data, 2018

Hasil uji reliabilitas didapat dari cronbach's Alpha sebesar 0,619 $\geq 0,6$. Karena ini diatas 0,6 maka dapat disimpulkan bahwa alat ukur dalam penelitian ini reliabel dan dapat dijadikan alat ukur untuk analisis selanjutnya.

Tabel .6

Rekapitulasi Hasil Uji Reliabilitas

\begin{tabular}{|c|c|c|c|c|}
\hline No & Variabel & $\begin{array}{c}\text { Cronbach's } \\
\text { Alpha Item }\end{array}$ & $\begin{array}{c}\text { Cronbach's } \\
\text { Alpha }\end{array}$ & keterangan \\
\hline 1 & Disiplin & 0,703 & 0,6 & Reliabel \\
\hline 2 & Kinerja & 0,619 & 0,6 & Reliabel \\
\hline
\end{tabular}

Sumber : data yang diolah dari kuesioner

Dilihat dari hasil pengujian data reliabilitas yang dilakukan dengan bantuan program SPSS versi 21, Cronbanch's Alpha Item yang lebih besar standar reabilitas yaitu 0,6 maka dapat disimpulkan untuk kedua variabel Cronbach's Alpha Item $\geq$ Nilai Cronbach's Alpha, maka dapat disimpulkan semua item pertanyaan yang ada pada instrumen tersebut dapat dijadikan sebagai alat ukur yang reliabel dalam analisis selanjutnya.

\section{b. Hasil Pengujian Regresi Linier Sederhana}

Tabel .7

Analisis Regresi Linear Sederhana Coefficients $^{\mathrm{a}}$

\begin{tabular}{|c|c|c|c|c|c|}
\hline \multirow[t]{2}{*}{ Model } & \multicolumn{2}{|c|}{$\begin{array}{c}\text { Unstandardized } \\
\text { Coefficients }\end{array}$} & $\begin{array}{l}\text { Standardized } \\
\text { Coefficients }\end{array}$ & \multirow[t]{2}{*}{$\mathrm{T}$} & \multirow[t]{2}{*}{ Sig. } \\
\hline & B & Std. Error & Beta & & \\
\hline (Constant) & 11,553 & 1,691 & & 6,834 &, 000 \\
\hline Disiplin & ,343 & ,090 & ,456 & 3,833 &, 025 \\
\hline
\end{tabular}

Sumber: data yang diolah penulis

Berdasarkan tabel diatas diketahui persamaan regresi sederhana sebagai berikut

$$
\begin{aligned}
& \mathrm{Y}=\mathrm{a}+\mathrm{bX} \\
& \mathrm{Y}=11,553+0,343 \mathrm{X}
\end{aligned}
$$

Berdasarkan persamaan ini, konstanta a sebesar 11,553 yang jika variabel bebas (disiplin) bernilai 0 maka variabel terikat (Kinerja) bernilai 11,553. Sedangkan koefisien regresi $\mathrm{b}$ sebesar $=0,343$ berarti jika variabel Disiplin meningkat sebesar 1 satuan maka variabel Kinerja meningkat sebesar b yaitu 0,343 satuan.

\section{c. Hasil Pengujian Koefisien Korelasi}

Korelasi menjelaskan hubungan antara variabel bebas (Variabel Disiplin) dengan Variabel Terikat (Kinerja) sedangkan koefisien determinasi menjelaskan seberapa besar kontribusi yang diberikan oleh variabel bebas (Disiplin) terhadap variabel Terikat (Kinerja).

Tabel. 8

\section{Koefisien Korelasi Uji}




\section{Model Summary}

\begin{tabular}{|l|r|r|r|r|}
\hline Model & $\mathrm{R}$ & $\mathrm{R}$ Square & $\begin{array}{c}\text { Adjusted R } \\
\text { Square }\end{array}$ & $\begin{array}{c}\text { Std. Error of the } \\
\text { Estimate }\end{array}$ \\
\hline 1 &, $456^{\mathrm{a}}$ &, 208 &, 194 & 2,275 \\
\hline
\end{tabular}

a. Predictors: (Constant), Disiplin

Sumber : Hasil olah data

Menurut Sugiyono (2012:250) pedoman untuk memberikan interprestasi koefisien korelasi sebagai berikut :

$$
\begin{aligned}
& 0,00-0,199=\text { Sangat Rendah } \\
& 0,20-0,399=\text { Rendah } \\
& 0,40-0,599=\text { Sedang } \\
& 0,60-0,799=\text { Kuat } \\
& 0,80-1,000=\text { Sangat Kuat }
\end{aligned}
$$

Karena nilai korelasi sederhana berada diantara $0,40-0,599$, maka dapat disimpulkan bahwa hubungan antara Disiplin dengan Kinerja berada pada kategori sedang.Nilai $r$ tabel untuk taraf kesalahan $10 \%$ dengan $n=58$ diperoleh $r$ tabel 0,266 karena nilai $r$ hitung lebih besar dari $r$ tabel untuk kesalahan $5 \%$ yaitu $(0,25$ $0,05)$, maka dapat disimpulkan terdapat hubungan yang positif sebesar 0,456 antara disiplin dan Kinerja.

\section{Hasil Pengujian Koefisien Determinasi}

Dalam analisi koefisien korelasi terdapat koefisien determinasi (r2) yang besarnya adalah kuadrat dari koefisien korelasi (r), koefisien ini disebut koefisien penentu. Dari hasil penggolahan data diperoleh nilai determinasi $\mathrm{r} 2=0,208$. Hal ini dapat diartikan bahwa Kinerja karyawan dipengaruhi oleh variabel Disiplin sebesar $20,8 \%$ sedangkan sisanya $70,2 \%$ dipengaruhi oleh variabel lain yang tidak diteliti pada penelitian ini.

\section{Hasil Pengujian Hipotesis (Uji t)}

Pengujian hipotesis dilakukan dengan uji t. Pengujian hipotesis bertujuan untuk menolak atau menerima hipotesis yang telah diajukan. maka dilakukan uji hipotesis dengan langkah-langkah sebagai berikut :

1. Menentukan tingkat signifikasi

Tingkat signifikasi menggunakan alpha $10 \%(0,1)$. Dari tabel C.6.nilai signifikansi $0,025 \leq 0,1$ yang artinya ada pengaruh signifikan.

2. Menentukan $t_{\text {tabel }}$

Tabel distribusi dicari pada alpha 10\% dengan derajad kebebasan (df) n-2 atau 58-2 = 56 ( $\mathrm{n}$ adalah jumlah kasus). Hasil diperoleh untuk $\mathrm{t}_{\text {tabel }}$ sebesar 1,684 (table $\mathrm{t}$ ).

3. Kesimpulan

Berdasarkan tabel C.6, dapat dilihat bahwa nilai $t_{\text {hitung }}$ untuk variabel Disiplin (X) adalah sebesar $(3,833) \geq t_{\text {tabel }}(1,684)$, oleh karena itu Ho ditolak dan Ha diterima, maka terdapat pengaruh yang signifikan antara Disiplin terhadap Kinerja Karyawan Pada PT. Lematang Tanjung Enim

\section{Pembahasan}

Analisis regresi sedehana menunjukkan konstanta a sebesar 11,553 artinya Disiplin (X) nilainya adalah 0 , maka kinerja (Y) nilainya sebesar 11,553. sedangkan koefisien regresi Variabel Kinerja (X) sebesar 0,343 artinya jika disiplin mengalami 
kenaikan sebesar 1, maka Kinerja (Y) akan mengalami peningkatan sebesar 0,343. Koefisien bernilai positif artinya ada pengaruh positif antara disiplin terhadap kinerja karyawannya, semakin bagus Disiplin yang diberikan maka akan meningkatkan kinerja karyawan .

Uji Hipotesis menunjukkan bahwa hipotesis alternatif diterima. Berdasarkan tabel.2. dapat dilihat bahwa nilai $t_{\text {hitung }}$ untuk variabel disiplin (X) adalah sebesar $(3,833)$, hal ini berarti $t_{\text {hitung }}(3,833) \geq t_{\text {tabel }}(1,684)$. Secara statistik terbukti adanya hubungan positif antara kedua variabel tersebut oleh karena itu Ho ditolak dan Ha diterima, hal ini berarti disiplin berpengaruh terhadap kinerja karyawan .

\section{Kesimpulan Dan Saran \\ Kesimpulan}

Berdasarkan hasil analisis dari variabel-variabel penelitian serta pengujian penulis membuat kesimpulan sebagai berikut :

1. Disiplin Kerja berpengaruh positif terhadap kinerja karyawan PT. Lematang di Tanjung Enim. Hal ini dibuktikan dengan nilai $t_{\text {hitung }}$ adalah sebesar 3,833 lebih besar dari $t_{\text {tabel }}$ yaitu 1,684.

2. Besarnya pengaruh disiplin kerja terhadap kinerja karyawan PT. Lematang di Tanjung Enim berdasarkan hasil perhitungan koefisien determinasi ialah sebesar $20,8 \%$ dan sisanya sebesar $70,2 \%$ dipengaruhi oleh faktor lain diluar penelitian ini.

3. Terdapat hubungan yang sedang antara kinerja karyawan PT. Lematang di Tanjung Enim yaitu 0,456 yang berarti jika variabel disiplin meningkat meningkat maka variabel kinerja mengalami kenaikan, begitupula sebaliknya apabila variabel disiplin mengalami penurunan maka variabel kinerja mengalami penurunan

\section{Saran-saran}

Berdasarkan hasil kesimpulan yang telah dikemukakan di atas, penulis mencoba memberikan beberapa saran yang dapat djadikan masukan bagi perusahaan yaitu :

1. Untuk meningkatkan disiplin kerja karyawan diharapkan pimpinan dapat selalu mengontrol, mengawasi dan membandingkan antara hasil pelaksanaan pekerjaan yang dilakukan karyawan dengan standar kerja yang telah ditetapkan. Hal ini bertujuan untuk menganalisis apabila terjadi penyimpangan maka dapat mengambil tindakan dengan cara memberikan sanksi berupa teguran lisan maupun tertulis.

2. Dalam upaya meningkatkan kinerja karyawan maka manajemen perusahaan dapat memberikan Reward atau bonus berupa financial kepada karyawan yang mempunyai prestasi kerja yang baik.

\section{DAFTAR PUSTAKA}

Hamali, Arif Yusuf. 2016. Pemahaman Manajemen Sumber Daya Manusia. Jakarta: Center For Academic Publishing Service.

Hasibuan SP Malayu (2017) Manajemen Sumber Daya Manusia ( Edisi Revisi ) Jakarta Indonesia : Bumi Aksara

L. Gaol, Jimmy. 2014. A to Z Human Capital Manajemen Sumber Daya Manusia Konsep, Teori, dan Pengembangan dalam Konteks Organisasi Publik dan Bisnis. Jakarta: PT. Grasindo Anggota IKAPI.

Mangkunegara, A. A. Anwar Prabu. 2015. Manajemen daya Manusia Perusahaan. Bandung: PT. Remaja Rosdakarya. 
Sugiyono. 2013. Metode Penelitian Bisnis (Pendekatan Kuantitatif, Kualitatif, dan $R \& D)$. Bandung: Alfabeta.

Sutrisno, Edy. 2009. Manajemen Sumber Daya Manusia. Jakarta: Prenadamedia Group.

Wirawan, 2012, Manajemen Sumber Daya Manusia Indonesia, Depok, Rajagrafindo Persada

Zainal, Veithzal Rivai, 2005. Manajemen Sumber Daya Manusia untuk perusahaan. Depok: PT. Rajagrafindo Persada.

Zainal, Veithzal Rivai, dkk. 2009. Manajemen Sumber Daya Manusia untuk perusahaan. Depok: PT. Rajagrafindo Persada. 